\title{
Pengaruh Kepemimpinan Kepala Raudhatul Athfal dan Regulasi Diri Guru terhadap Kinerja Guru di PC Cilimus Kabupaten Kuningan
}

\author{
Lesi Sri Lestari', Mira Mayasarokh ${ }^{2}$ \\ PG-PAUD STKIP Muhammadiyah Kuningan ${ }^{1,2}$ \\ Email: lesisrilestari888@gmail.com ${ }^{1}, \underline{\text { mira@upmk.ac.id }}{ }^{2}$
}

\begin{abstract}
Abstrak:
Kepala sekolah merupakan salah satu komponen pendidikan yang berpengaruh dalam meningkatkan kinerja guru. Sementara itu dari sisi internal salah satu faktor yang dapat mempengaruhi kinerja guru adalah regulasi diri guru. Tujuan dari penelitian ini adalah untuk mengetahui: (1) seberapa besar pengaruh kepemimpinan kepala RA terhadap kinerja guru di PC Cilimus Kab. Kuningan; (2) seberapa besar pengaruh regulasi diri guru terhadap kinerja guru RA di PC Cilimus Kab. Kuningan; dan (3) seberapa besar pengaruh kepemimpinan kepala RA dan regulasi diri guru terhadap kinerja guru di PC Cilimus Kab. Kuningan. Metode penelitian yang digunakan adalah pendekatan kuantitatif dengan jenis penelitian ex-post facto. Populasi dan sampel dalam penelitian ini adalah guru Raudhatul Athfal di PC Cilimus Kabupaten Kuningan yang berjumlah 61 guru dari 23 lembaga. Instrumen pengumpulan data berupa kuesioner dengan skala likert yang memiliki 4 alternatif jawaban. Analisis data menggunakan teknik analisis regresi linear berganda dengan pengujian hipotesis uji parsial (Uji t) dan uji simultan (Uji F) menggunakan software SPSS 20. Hasil penelitian menunjukkan: (1) Kepemimpinan kepala RA berpengaruh positif signifikan terhadap kinerja guru sebesar 1,202; kemudian (2) Regulasi diri guru berpengaruh positif tidak signifikan terhadap kinerja guru sebesar 0,469; dan (3) Kepemimpinan kepala RA dan regulasi diri guru secara bersama-sama berpengaruh signifikan terhadap kinerja guru sebesar 90,7\%, sedangkan 9,3\% lainnya dijelaskan oleh variabel lain yang tidak termasuk dalam penelitian ini.
\end{abstract}

Kata kunci: Kepemimpinan Kepala RA, Regulasi Diri, Kinerja Guru

\begin{abstract}
The principal is one of the components of education that is influential in improving teacher performance. Meanwhile, from the internal side, one of the factors that can affect teacher performance is teacher self-regulation. The purpose of this study was to determine: (1) how much influence the leadership of the head of Raudhatul Athfal on the performance of teachers in the Head of Branch Cilimus Kab. Brass; (2) how much influence does teacher self-regulation have on the performance of Raudhatul Athfal teachers at the Cilimus Branch Management, Kuningan Regency; and (3) how much influence the leadership of the head of Raudhatul Athfal and teacher self-regulation on the performance of teachers in the Head of Cilimus Branch, Kuningan Regency. The research method used is a quantitative approach with the type of ex-post facto research. The population and sample in this study were Raudhatul Athfal teachers at the Cilimus Branch Office in Kuningan Regency, totaling 61 teachers from 23 institutions. The data
\end{abstract}

Pengaruh Kepemimpinan Kepala (Lestari, Mayaksarokh) 251 
collection instrument was a questionnaire with a Likert scale which had 4 alternative answers. Data analysis used multiple linear regression analysis techniques with partial test hypothesis testing (t test) and simultaneous test (F test) using SPSS 20 software. The results showed: (1) the leadership of the head of Raudhatul Athfal has a significant positive effect on teacher performance by 1.202; then (2) teacher self-regulation has no significant positive effect on teacher performance of 0.469; and (3) Raudhatul Athfal leadership and teacher self-regulation together have a significant effect on teacher performance by $90.7 \%$, while the other $9.3 \%$ are explained by other variables not included in this study.

Keywords: Principal Leadership, Self Regulation, Teacher Performance

\section{PENDAHULUAN}

Salah satu sumber daya atau komponen yang harus dikelola dalam lembaga PAUD adalah guru. Guru mendapatkan perhatian yang besar karena guru merupakan sumber daya potensial yang turut berperan dalam mewujudkan tujuan pendidikan nasional. Guru merupakan pihak yang terlibat langsung dalam proses pembelajaran serta memiliki peran yang sangat vital dalam meningkatkan kualitas anak didiknya. Tugas Keprofesionalan Guru menurut UU RI Nomor 14 Tahun 2005 pasal 20 (a) tentang Guru dan Dosen adalah merencanakan pembelajaran, melaksanakan proses pembelajaran yang bermutu serta menilai dan mengevaluasi hasil pembelajaran. Tugas pokok guru tersebut yang diwujudkan dalam kegiatan belajar mengajar serta tugas-tugas guru dalam kelembagaan merupakan bentuk kinerja guru. Apabila kinerja guru meningkat maka berpengaruh pada peningkatan kualitas keluaran atau outputnya.

Fenomena yang ditemukan di lapangan berdasarkan hasil pengamatan dan wawancara, kondisi kinerja guru PAUD di kota Kuningan menunjukkan bahwa terdapat beberapa guru yang kurang memahami materi pelajaran sesuai dengan kurikulum yang telah ditetapkan, sehingga mereka seringkali melakukan kegiatan pembelajaran yang berbeda dengan kurikulum. Sedangkan dalam hal melakukan kegiatan administrasi seperti pencatatan dan pelaporan hasil belajar siswa, guru sering merasa kesulitan karena kepala sekolah jarang memberikan bantuan dalam hal administratif, karena berpikir itu menjadi tanggung jawab penuh guru. Selain itu, dalam pelaksanaan tugas mendidik, guru memiliki sifat dan perilaku yang berbeda, ada yang bersemangat dan penuh tanggung jawab dan ada juga yang sebaliknya. Kondisi seperti itulah yang menjadi permasalahan di setiap lembaga PAUD.

Donni Juni Priansa (2014: 269) menuliskan bahwa kinerja merupakan perwujudan dari kemampuan dalam bentuk karya nyata. Nurlaila (2010: 71) juga mengatakan kinerja merupakan hasil atau keluaran dari suatu proses. Selain itu, menurut Mulyasa (2013: 88) kinerja adalah unjuk kerja seseorang yang ditunjukkan dalam penampilan, perbuatan, dan prestasi kerjanya sebagai akumulasi dari pengetahuan, keterampilan, nilai dan sikap yang telah dimilikinya. Kinerja adalah cara di mana seorang staf dalam sebuah organisasi melakukan tugas yang 
ditugaskan kepadanya untuk mewujudkan tujuan dan sasaran organisasi (Okoji, 2015). Berdasarkan beberapa pendapat tersebut, maka dapat disimpulkan bahwa kinerja merupakan penampilan atau unjuk kerja seseorang dalam menjalankan peran dan fungsinya dalam suatu lingkungan tertentu termasuk dalam organisasi untuk memperoleh hasil kerja yang optimal dalam waktu yang telah ditetapkan.

Guru adalah pendidik profesional dengan tugas utama mendidik, mengajar, mengarahkan, menilai dan mengevaluasi peserta didik pada PAUD jalur formal, pendidikan dasar, dan pendidikan menengah (PP 19, 2005). Guru merupakan jantungnya kualitas pendidikan. Guru TK yang profesional harus mampu mengenali kebutuhan dan karakteristik anak didiknya sehingga pencapaian tujuan pendidikan di TK dapat tercapai secara optimal. Bagus tidaknya kualitas pendidikan di TK akan tergantung dari kinerja guru yang melaksanakan proses pembelajaran.

Secara formal kepala sekolah adalah pemimpin resmi di sekolah, karena ada legitimasi dari pihak yang berkuasa dan berwenang baik dari pemerintah ataupun Yayasan. Dengan legitimasi ini dia bisa memaksa bawahan (guru dan staf TU) untuk tunduk dan patuh pada perintahnya. Paling penting dalam memanfaatkan kekuasaannnya kepala sekolah diharapkan mempunyai keahlian yang dikaitkan dengan profesionalisme pekerjaannya. Kepemimpinan kepala sekolah dalam mengarahkan dan memanfaatkan segala sumberdaya yang tersedia sangat menentukan keberhasilan proses belajar di sekolah. Guna mewujudkan tanggung jawab tersebut, maka kepala sekolah sangat berperan dalam mengendalikan keberhasilan kegiatan pendidikan, meningkatkan pelaksanaan administrasi sekolah sesuai dengan pedoman, meningkatkan keterlaksanaan tugas tenaga kependidikan sesuai dengan tujuan pendidikan, dan mengatur secara profesional pendayagunaan serta memelihara sarana dan prasarana pendidikan.

kepemimpinan yang baik adalah pemimpin yang dapat menciptakan kepemimpinaannya yang efektif. Kepemimpinan yang efektif dapat melaksanakan dan memanfaatkan peran dan fungsi manajemen pengelolaan PAUD dengan baik termasuk melaksanakan perencanaan program kerja. Apabila kepemimpinan kepala sekolah dapat dijalankan dengan baik dan profesionalitas yang tinggi maka dapat terwujud adanya peningkatan kinerja guru PAUD.Sementara itu dari sisi internal, salah satu faktor yang dapat mempengaruhi kinerja guru adalah regulasi diri guru. Menurut Pintrich \& De Groot (1990), regulasi diri merupakan suatu kegiatan belajar yang diatur oleh diri sendiri, yang di dalamnya individu mengaktifkan pikiran, motivasi, dan tingkah lakunya untuk mencapai tujuan. Kemampuan individual untuk memiliki pengendalian diri dalam dirinya sendiri, itulah yang menjadi sorotan penting dalam regulasi diri (Prasad, Lim, \& Chen, 2010). Carver dan Scheier mengungkapkan pengertian regulasi diri sebagai proses di mana organisme mengejar tujuan yang penting. Proses regulasi diri meliputi penetapan tujuan, pengawasan kemajuan dan membuat penyesuaian dalam perilaku dalam mencapai hasil-hasil yang diharapkan. (King, 2010: 92-93) 
Menurut Bandura, Schunk dan Zimmerman (dalam Ormrod, 2011: 132-133) regulasi diri terdiri dari 5 aspek yaitu 1) mengatur standar dan tujuan (setting standards and goals), 2) observasi diri (self-observation), 3) evaluasi diri (self-evaluation), 4) reaksi diri (self-reaction), dan 5) refleksi diri (self-reflection).

Dari beberapa pendapat ahli tersebut dapat disimpulkan bahwa regulasi diri ialah kemampuan individu untuk mengontrol perilakunya, mengendalikan pikiran, perasaan, dorongan, dan hasrat mereka dalam rangka mencapai suatu tujuan. Regulasi diri meliputi beberapa proses yaitu mengatur, merencanakan, mengarahkan dan memonitor perilaku.

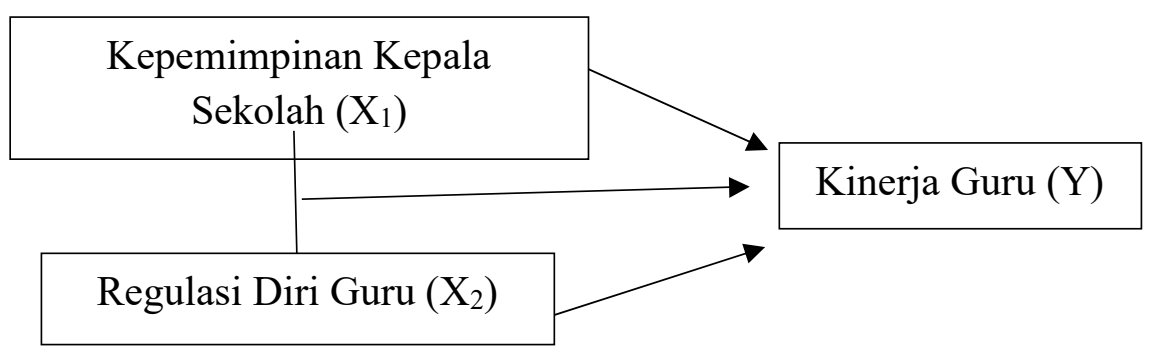

$$
\begin{aligned}
& \text { Keterangan: } \\
& \mathrm{X}_{1}=\text { Kepemimpinan kepala sekolah } \\
& \mathrm{X}_{2} \quad=\text { Regulasi diri guru } \\
& \mathrm{Y} \quad=\text { Kinerja guru }
\end{aligned}
$$

\section{Gambar 1 Skema Pengaruh Kepemimpinan Kepala Sekolah dan Regulasi Diri Guru terhadap Kinerja Guru}

Berdasarkan rumusan penelitian tersebut, penelitian ini bertujuan untuk mengetahui: (1) seberapa besar pengaruh kepemimpinan kepala Raudhatul Athfal terhadap kinerja guru di PC Cilimus Kab. Kuningan; (2) seberapa besar pengaruh regulasi diri guru terhadap kinerja guru Raudhatul Athfal di PC Cilimus Kab. Kuningan; dan (3) seberapa besar pengaruh kepemimpinan kepala Raudhatul Athfal dan regulasi diri guru terhadap kinerja guru di PC Cilimus Kab. Kuningan.

\section{METODE PENELITIAN}

Penelitian ini menggunakan pendekatan kuantitatif, karena data yang diperoleh berupa angka-angka dan pengolahannya menggunakan metode statistik yang digunakan lalu diinterpretasikan. Jenis penelitian ini yaitu ex-post facto karena hanya mengungkapkan data peristiwa yang sudah berlangsung dan telah ada pada responden tanpa memberikan perlakukan atau manipulasi terhadap variabel yang diteliti. Jenis penelitian ini dipilih karena peneliti bermaksud untuk mengungkapkan seberapa besar pengaruh variabel bebas (kepemimpinan 
kepala sekolah dan regulasi diri guru) terhadap variabel terikat (kinerja guru). Populasi dalam penelitian ini adalah kepala sekolah dan guru Raudhatul Athfal di PC Cilimus Kabupaten Kuningan yang berjumlah 61 orang dari 23 lembaga RA. Teknik utama dalam penelitian ini yaitu angket dengan menggunakan skala likert dan teknik pendukung penelitian berupa studi dokumentasi. Metode studi dokumentasi dalam penelitian ini digunakan untuk mengetahui jumlah guru. Selanjutnya angket (questionnaire) untuk mengetahui tentang data kepemimpinan kepala RA dan regulasi diri guru terhadap kinerja guru. Angket yang digunakan untuk mengumpulkan data dalam penelitian ini telah dinyatakan valid. Penelitian ini diuji menggunakan teknik analisis regresi linear berganda dengan pengujian hipotesis uji parsial (uji t) dan uji simultan (uji F) untuk mengetahui pengaruh variabel-variabel yang terkait dalam penelitian dan koefisien determinasi. Model regresi berganda harus memenuhi asumsi klasik. Uji asumsi klasik bertujuan untuk mengetahui apakah model regresi yang diperoleh dapat menghasilkan estimator linier yang baik. Apabila dalam suatu model telah memenuhi asumsi klasik, maka dapat dikatakan model tersebut sebagai model ideal atau menghasilkan estimator linier tidak bias yang terbaik atau Best Linier Unbias Estimator (BLUE). Model regresi perlu diuji dengan asumsi klasik karena kriteria BLUE diatas, yang dilakukan dengan uji normalitas, uji multikolinearitas, dan uji heteroskedastisitas dengan bantuan software SPSS 20.

\section{HASIL DAN PEMBAHASAN}

Penelitian ini menggunakan tiga variabel, variabel bebasnya yaitu kepemimpinan kepala sekolah dan regulasi diri. Sedangkan variabel terikatnya yaitu kinerja guru. Kepemimpinan kepala sekolah diukur dengan menggunakan kuesioner yang diberikan kepada 61 guru yang merupakan anggota populasi dari guru-guru Raudhatul Athfal di PC Cilimus Kabupaten Kuningan. Angket tersebut menggunakan model skala likert, dimana setiap jawaban memiliki skor yang berbeda. Variabel kepemimpinan kepala sekolah diukur dengan pertanyaan sebanyak 40 butir. Regulasi diri guru diukur dengan pertanyaan sebanyak 24 butir. Kinerja guru diukur dengan pertanyaan sebanyak 60 butir.

Berikut ini adalah hasil uji normalitas, uji multikolinearitas, uji heteroskedastisitas, uji regresi, dan analisi koefisien determinasi: 


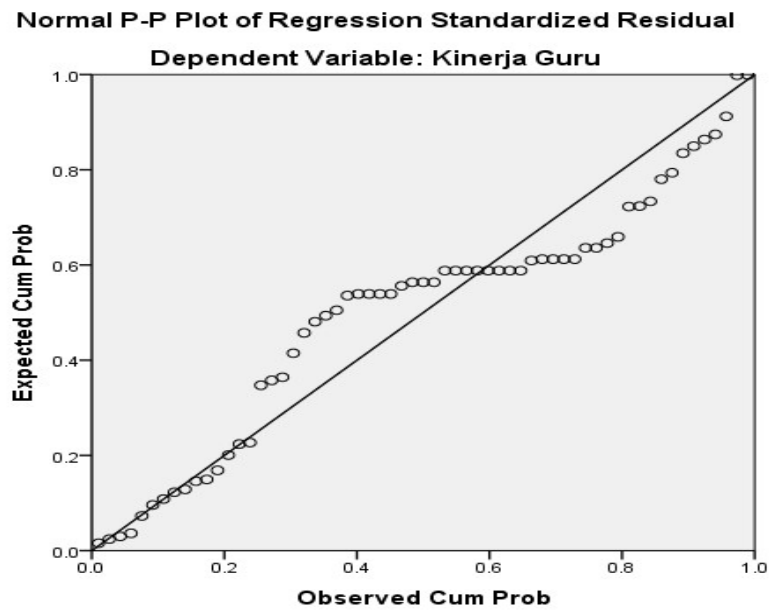

Gambar 1 Hasil Uji Normalitas

Dari hasil uji normalitas pada gambar 1 di atas dapat disimpulkan bahwa distribusi data dalam penelitian berdistribusi normal, karena data ploting (titik-titik) yang menggambarkan data sesungguhnya mengikuti garis diagonal. Hal itu sejalan dengan pendapat Imam Ghozali (2011:161) model regresi dikatakan berdistribusi normal jika data ploting (titik-titik) yang menggambarkan data sesungguhnya mengikuti garis diagonal.

\section{Tabel 1 Hasil Uji Multikolinearitas}

\begin{tabular}{|c|c|c|c|c|c|c|c|}
\hline & & & Coefficients $^{\mathrm{a}}$ & & & & \\
\hline \multirow[t]{2}{*}{ Model } & \multicolumn{2}{|c|}{$\begin{array}{l}\text { Unstandardized } \\
\text { Coefficients }\end{array}$} & $\begin{array}{l}\text { Standardized } \\
\text { Coefficients }\end{array}$ & \multirow[t]{2}{*}{$\mathrm{t}$} & \multirow[t]{2}{*}{ Sig. } & \multicolumn{2}{|c|}{ Collinearity Statistics } \\
\hline & $\mathrm{B}$ & Std. Error & Beta & & & Tolerance & VIF \\
\hline (Constant) & 1.924 & 9.421 & & .204 & .839 & & \\
\hline $1 \begin{array}{l}\text { Kepemimpinan } \\
\text { Kepala Sekolah }\end{array}$ & 1.202 & .144 & .799 & 8.370 & .000 & .171 & 5.842 \\
\hline Regulasi Diri & .469 & .267 & .168 & 1.758 & .084 & .171 & 5.842 \\
\hline
\end{tabular}

a. Dependent Variable: Kinerja Guru

Dari tabel 1 tersebut hasil uji multikoliniaritas nilai VIF kurang dari 10 dan nilai tolerance mendekati 1 sehingga dapat disimpulkan bahwa data dalam penelitian ini tidak terjadi multikoliniearitas diantara variabel bebasnya. Hal itu sesuai dengan pendapat Imam Ghozali (2002:64) mengatakan bahwa regresi bebas dari multikolinearitas apabila nilai VIF multikolinearitas adalah kurang dari 10 dan tolerance mendekati 1. 
Scatterplot

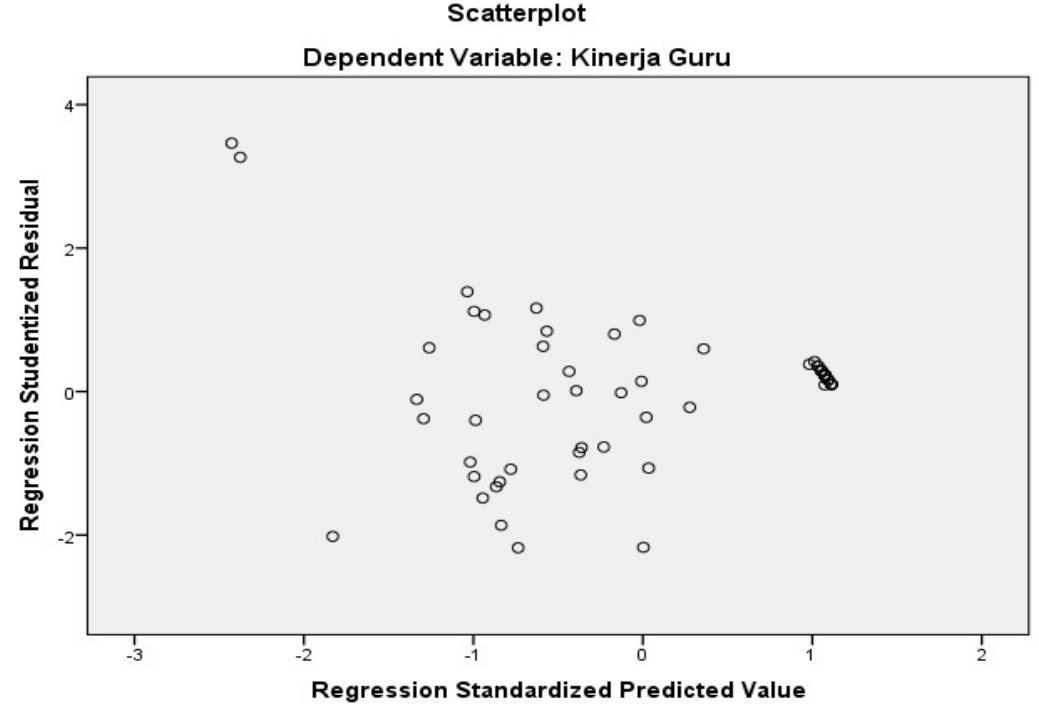

Gambar 2 Hasil Uji Heteroskedastisitas

Dari gambar 2 diatas dapat disimpulkan bahwa grafik terlihat tidak ada pola yang jelas, serta titik-titik menyebar di atas dan di bawah angka 0 pada sumbu Y, maka tidak terjadi heteroskedastisitas.

Tabel 2 Hasil Pengujian Hipotesis dengan Uji Parsial (Uji t)

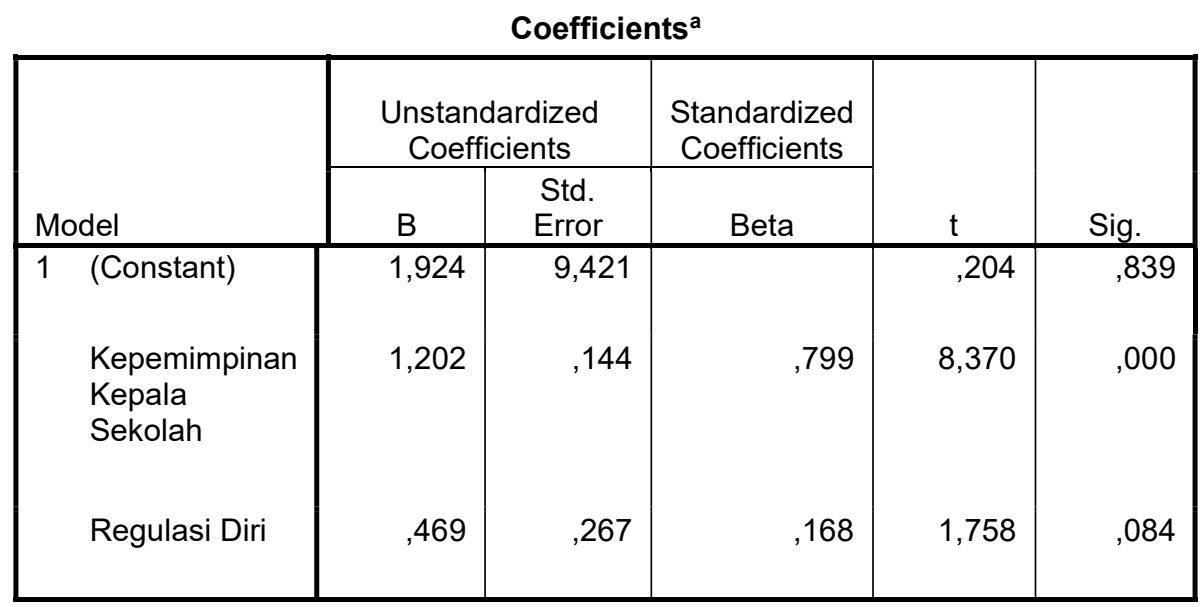

a. Dependent Variable: Kinerja Guru

Berdasarkan hasil perhitungan pada tabel 2, hasil persamaan regresi dalam penelitian ini adalah : $\mathrm{Y}=1,924+1,202 \mathrm{X}_{1}+0,469 \mathrm{X}_{2}$

Berdasarkan hasil uji regresi $\mathrm{Y}=\mathrm{a}+\mathrm{b} . \mathrm{X}$ atau $\mathrm{Y}=1,924+1,202 \mathrm{X}_{1}$ Semakin tinggi variabel kepemimpinan maka semakin baik kinerja guru. Apabila kepemimpinan baik kinerja juga akan 
baik hal ini dipengaruhi oleh perilaku pemimipin dengan fungsi kepemimpinan yaitu charisma (memiliki karisma), Idealized Influence (idealisme), inspirational motivation (memiliki motivasi inspirasi), intellectual stimulation (intelektual), dan individualized consideration (kepedulian terhadap individu guru).

Nilai koefisien regresi variabel kepemimpinan bernilai positif yaitu sebesar 1,202, artinya jika variabel kepemimpinan mengalami peningkatan sebesar $1 \%$ sedangkan regulasi diri diasumsikan tetap, maka akan menyebabkan peningkatan kepemimpinan sebesar 1,202. Nilai koefisien tersebut menunjukkan bahwa nilai kepemimpinan kepala sekolah berpengaruh positif terhadap kinerja guru. Hal ini menggambarkan ketika nilai kepemimpinan naik, maka kinerja akan naik. Berdasarkan uji hipotesis menunjukkan bahwa kepemimpinan kepala sekolah memiliki pengaruh yang positif dan signifikan terhadap kinerja guru. Hal ini ditunjukkan dengan nilai $\mathrm{t}$ hitung $8,370>\mathrm{t}$ tabel 1,671 dan taraf signifikan $0,000<0,05$. Sehingga terdapat pengaruh positif signifikan antara kepemimpinan kepala sekolah $\left(\mathrm{X}_{1}\right)$ terhadap kinerja guru $(\mathrm{Y})$.

Penelitian ini juga didukung dan diperkuat oleh penelitian yang dilakukan oleh Heni Nafikoh yang berjudul Pengaruh Kepemimpinan Kepala Sekolah dan Motivasi Berprestasi Terhadap Kinerja Guru Pendidikan Anak Usia Dini yang menyatakan bahwa hasil penelitian menunjukkan terdapat pengaruh yang sangat tinggi antara kepemimpinan kepala sekolah (X1) terhadap kinerja mengajar guru (Y). Selanjutnya, berdasarkan hasil uji regresi $Y=a+b . X$ atau $\mathrm{Y}=1,924+0,469 \mathrm{X}$ Semakin tinggi variabel regulasi diri guru maka semakin baik kinerja guru. Apabila regulasi diri guru baik kinerja juga akan baik hal ini dipengaruhi oleh aspek-aspek regulasi diri yang terdiri dari mengatur standar dan tujuan (setting standards and goals), observasi diri (self-observation), evaluasi diri (self-evaluation), reaksi diri (self-reaction), serta refleksi diri (self-reflection). Nilai koefisien regresi variabel regulasi diri guru bernilai positif yaitu sebesar 0,469, artinya jika variabel regulasi diri mengalami peningkatan sebesar 1\% sedangkan kepemimpinan diasumsikan tetap, maka akan menyebabkan peningkatan regulasi diri sebesar 0,469. Nilai koefisien tersebut menunjukkan bahwa nilai regulasi diri berpengaruh positif terhadap kinerja guru. Hal ini menggambarkan ketika nilai regulasi diri guru naik, maka kinerja guru akan naik. Berdasarkan uji hipotesis menunjukkan regulasi diri guru berpengaruh positif tidak signifikan ditunjukkan dengan angka t hitung 1,758 $>$ t tabel 1,671 dan taraf signifikan $0,84>0,05$. Sehingga terdapat pengaruh positif tidak signifikan antara regulasi diri guru terhadap kinerja guru.

Dapat disimpulkan bahwa koefisien standar (standardized Coefficients) pada tabel 2 di atas, digunakan untuk mengetahui pengaruh variabel bebas yaitu : kepemimpinan kepala sekolah $\left(\mathrm{X}_{1}\right)$, regulasi diri guru $\left(\mathrm{X}_{2}\right)$, terhadap kerja guru $(\mathrm{Y})$. Dari kedua variabel tersebut di atas maka dapat dilihat besarnya koefisien regresinya 1,924 kepemimpinan kepala sekolah $\left(\mathrm{X}_{1}\right)=1,202$ regulasi diri guru $\left(\mathrm{X}_{2}\right)=0,469$. Hasil tersebut menunjukkan bahwa kepemimpinan kepala sekolah $\left(\mathrm{X}_{1}\right)$ mempunyai pengaruh terbesar terhadap kinerja guru $(\mathrm{Y})$ dan regulasi diri guru $\left(\mathrm{X}_{2}\right)$ yang memiliki pengaruh terendah terhadap kerja guru (Y). 
Tabel 3 Hasil Pengujian Hipotesis dengan Uji Simultan (Uji F)

\begin{tabular}{|c|c|c|c|c|c|}
\hline \multicolumn{6}{|c|}{ ANOVA $^{a}$} \\
\hline Model & $\begin{array}{l}\text { Sum of } \\
\text { Squares }\end{array}$ & $d f$ & $\begin{array}{l}\text { Mean } \\
\text { Square }\end{array}$ & $\mathrm{F}$ & Sig. \\
\hline 1 Regression & 33069,619 & 2 & 16534,809 & 291,909 & $.000^{\mathrm{b}}$ \\
\hline Residual & 3285,332 & 58 & 56,644 & & \\
\hline Total & 36354,951 & 60 & & & \\
\hline
\end{tabular}

Tabel menunjukan apabila $F_{\text {hitung }} \leq F_{\text {tabel, }}$ maka $H_{o}$ dapat diterima dan jika $F_{\text {hitung }} \geq F_{\text {tabel }}$ maka $\mathrm{H}_{\mathrm{a}}$ diterima atau signifikan. Bisa juga menggunakan nilai probabilitas. Apabila nilai significance $F<\alpha$ (alpha), maka hipotesis penelitian dapat diterima. Dengan membandingkan statistik hitung dengan statistik tabel maka berdasarkan tabel di atas besarnya Fhitung $=291,909$, sedangkan F tabel ditentukan berdasarkan derajat kesalahan atau $\alpha=5 \%$ dan derajat kebebasan, $\mathrm{dk}$ pembilang $=\mathrm{k}$ dan dk penyebut (n-k) dari tabel akan didapat $\mathrm{F}(\alpha=5 \%$, dk pembilang $=2 \mathrm{dk}$ penyebut $=61)$. Berdasarkan perhitungan, maka dapat dinyatakan bahwa Fhitung $>$ Ftabel yaitu 291,909 $>2,59$ yang berarti bahwa ada pengaruh yang signifikan secara simultan antara variabel independen terhadap variabel dependen.

Berdasarkan probabilitas pada tabel 3 di atas, Fhitung sebesar 291,909 dengan tingkat signifikansi 0,000 jauh lebih kecil dari level significance yang digunakan yakni sebesar 0,05 maka $\mathrm{H}_{0}$ ditolak dan $\mathrm{H}_{1}$ diterima yang berarti hipotesis penelitian yang menyatakan bahwa terdapat pengaruh antara kepemimpinan kepala sekolah dan regulasi diri terhadap kinerja guru secara simultan dapat diterima. Dari hasil di atas diketahui bahwa kinerja guru dipengaruhi oleh kepemimpinan kepala sekolah dan regulasi diri guru sehingga apabila kinerja guru ingin meningkat maka harus ada pengelolaan kepemimpinan dan regulasi diri secara optimal. Berdasarkan hasil uji regresi $\mathrm{Y}=1,924+1,202 \mathrm{X}_{1}+0,469 \mathrm{X}_{2}$, apabila lembaga meningkatkan kepemimpinan dan regulasi diri sebanyak satu satuan maka kinerja juga akan naik sebanyak satu satuan.

Tabel 4 Analisis Koefisien Determinasi

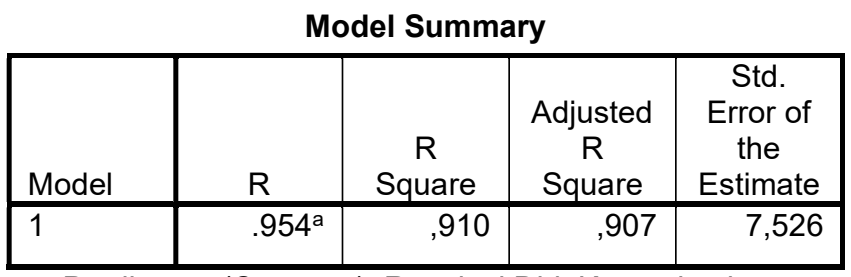

a. Predictors: (Constant), Regulasi Diri, Kepemimpinan Kepala Sekolah 
Nilai koefisien determinasi adalah Adjusted R Square yaitu sebesar 0.907 atau sebesar 90,7\%. Hal ini berarti bahwa pengaruh variabel kepemimpinan kepala sekolah ( $\left.\mathrm{X}_{1}\right)$, variabel regulasi diri $\left(\mathrm{X}_{2}\right)$ secara bersama-sama berpengaruh terhadap variabel kinerja guru $(\mathrm{Y})$ adalah sebesar $90,7 \%$ sedangkan sisanya sebesar 9,3\% dipengaruhi oleh variabel lain yang tidak termasuk dalam penelitian ini.

\section{KESIMPULAN}

Berdasarkan hasil analisis data yang dilakukan oleh penulis maka dapat disimpulkan bahwa kepemimpinan kepala Raudhatul Athfal berpengaruh positif signifikan terhadap kinerja guru sebesar 1,202. Sehingga semakin baik kepemimpinan yang tercipta semakin meningkat pula kinerja guru, dan demikian pula sebaliknya semakin buruk kepemimpinan maka kinerja guru juga semakin buruk. Regulasi diri guru berpengaruh positif tidak signifikan terhadap kinerja guru sebesar 0,469. Sehingga semakin baik regulasi diri yang tercipta semakin meningkat pula kinerja guru, dan demikian pula sebaliknya semakin buruk regulasi diri maka kinerja guru juga semakin buruk. Kepemimpinan kepala RA dan regulasi diri guru secara bersama-sama berpengaruh signifikan terhadap kinerja guru sebesar 90,7\%, sedangkan 9,3\% lainnya dijelaskan oleh variabel lain yang tidak termasuk dalam penelitian ini. Sehingga apabila kinerja guru ingin meningkat maka harus ada pengelolaan kepemimpinan dan regulasi diri secara optimal.

\section{DAFTAR PUSTAKA}

Afrina, D. (2019). Hubungan Kepemimpinan Instruksional Kepala Sekolah Dan Efikasi Diri Dengan Kinerja Mengajar Guru. Manajer Pendidikan, 13(2), 146-157.

Aguswara, Winda W., \& Reza Rachmadtullah. (2018). Pengaruh Gaya Kepemimpinan Kepala Sekolah dan Iklim Organisasi dengan Kinerja Guru Pendidikan Anak Usia Dini. Jurnal Pendidikan Usia Dini, 11(2). https://doi.org/10.21009/JPUD.112.14

Aryawan, I. W. (2019). Strategi Kepemimpinan Kepala Sekolah Di Era Revolusi Industri 4.0 Berlandaskan Pada Konsep Panca Upaya Sandhi. Jurnal Ilmiah Ilmu Sosial, 5(2), 132-141.

Ghozali, Imam. (2002). Aplikasi Analisis Multivariate dengan Program SPSS. Semarang: Badan Penerbit Universitas Diponegoro

Halimah, S., Rahman, I. K., \& Hakiem, H. (2019). Hubungan regulasi diri dengan disiplin kerja guru PAI di MTS kota dan kabupaten bogor. e-Jurnal Mitra Pendidikan, 3(4), 519-530.

Huda, M. (2018). Tugas Kepemimpinan Kepala Sekolah Dalam Manajemen Berbasis Sekolah. al-Afkar, Journal For Islamic Studies, 1(2, July), 46-54.

Husaini Usman. (2008). Manajemen, Teori, Praktik, dan Riset Pendidikan. Jakarta: Bumi Aksara

Ideswal, I., Yahya, Y., \& Alkadri, H. (2020). Kontribusi Iklim Sekolah dan Kepemimpinan Kepala Sekolah terhadap Kinerja Guru Sekolah Dasar. Jurnal Basicedu, 4(2), 460-466.

King, Laura A. (2010). Psikologi Umum: Sebuah Pandangan Apresiatif. Alih bahasa: Brian Marwensdy. Jakarta: Salemba Humanika. 
Maharani, Dyah. (2015). Pengaruh Perilaku Kepemimpinan Kepala Sekolah dan Motivasi Kerja terhadap Kinerja Mengajar Guru TK. Jurnal Administrasi Pendidikan, 22(1), 102-113.

Mbuik, H. B. (2019). Pengaruh Kepemimpinan Kepala Sekolah terhadap Penerapan Manajemen Berbasis Sekolah di SD. Indonesian Journal of Primary Education, 3(2), 28-37.

Mulyasa, E. (2009). Menjadi Guru Profesional Menciptakan Pembelajaran Kreatif dan Menyenangkan. Bandung: Remaja Rosdakarya

Mulyasa, H. E. (2013). Uji Kompetensi dan Penilaian Kinerja Guru. Bandung: Remaja Rosdakarya

Nafiqoh, Heni. (2017). Pengaruh Kepemimpinan Kepala Sekolah dan Motivasi Berprestasi terhadap Kinerja Guru Pendidikan Anak Usia Dini. 3(1), 57-75.

Nurlaila. (2010). Manajemen Sumber Daya Manusia. Ternate: Lepkhair

Okoji, O. O. (2015). Relationship between School Principals' Leadership Styles and Teachers' Job Performance in Ondo State Nigeria. Ife Psychologia, 23(2), 133-138. https://doi.org/ISSN:1117-1421

Ormrod, Jeanne Ellis. (2011). Human Learning. 6th. ed. New York: Pearson.

Permadi. D., \& Arifin Daeng. 2010. Kepemimpinan Transgormasional Kepala Sekolah dan Komite Sekolah. Bandung: PT Sarana Panca Karya Nusa

Prasad, S., Lim, V. K. G., \& Chen, D. J. Q. (2010). Self-Regulation, Individual Characteristics and Cyberloafing. PACIS Proceedings, 152.

Priansa, Donni Juni. (2014). Kinerja Dan Profesionalisme Guru Fokus pada Peningkatan Kualitas Pendidikan, Sekolah, dan Pembelajaran. Bandung: Alfabeta

Sulfemi, W. B. (2020). Pengaruh Rasa Percaya Diri dan Gaya Kepemimpinan Kepala Sekolah Terhadap Kinerja Guru. Nidhomul Haq: Jurnal Manajemen Pendidikan Islam, 5(2), 157 179.

Wahjosumidjo. (2010). Kepemimpinan Kepala Sekolah; Tinjauan Teoritik dan Permasalahannya. Jakarta: Raja Grafindo Persada

Wulandari, Trie. (2015). Analisis Kinerja Guru dalam Mengelola Pembelajaran Anak Usia Dini. Jurnal Pendidikan dan Pembelajaran Untan, 4(11) 